\title{
ARTYKULY
}

Magdalena Ujma

(Uniwersytet Opolski)

\section{ARCHIWA PRYWATNE RODZIN SZLACHECKICH Z POGRANICZA PODLASIA, LITWY I LUBELSZCZYZNY W XVIII-XIX W. (W ŚWIETLE ZBIORU ZYGMUNTA GLOGERA W ARCHIWUM PAŃSTWOWYM NA WAWELU)}

W yeksponowana pozycja stanu szlacheckiego, a także postępujący powoli zmierzch ustroju stanowego w XVIII/XIX w., skłaniały badaczy do dokładniejszego zbadania materialnych podstaw politycznego znaczenia warstw uprzywilejowanych ${ }^{1}$. Nie bez znaczenia były także relacje między najbardziej liczącymi się rodami szlacheckimi i magnackimi na przestrzeni dziejów, co umożliwia między innymi określenie dróg karier i przyczyn upadku posiadanej pozycji społecznej i politycznej². Podstawowym źródłem wiedzy na ten temat są dokumenty i akta przechowywane niegdyś w archiwach prywatnych ${ }^{3}$. Ich niekompletność, a często szczątkowy stan zachowania, zmusza badacza do poszukiwania rozproszonych archiwaliów umożliwiających wgląd w działalność organizacyjną i gospodarczą folwarków średnioszlacheckich i latyfundiów magnackich. Zespoły archiwalne nazywane archiwami podworskimi ułatwiają pracę dzięki skomaso-

${ }^{1}$ Zob. m.in. A. Mączak, Pieniądz i społeczeństwo w Rzeczypospolitej XVI-XVIII wieku, „Rocznik Dziejów Społecznych i Gospodarczych” 1976, t. 37; J. Półćwiartek, Latyfundium rzeszowskie, [w:] Dzieje Rzeszowa, t. 1, Rzeszów 1994.

${ }^{2}$ K. Karolczak, Dzieduszyccy. Dzieje rodu. Linia poturzycko-zarzecka, Kraków 2001; M. Kowalski, Państwo magnackie w strukturach polityczno-administracyjnych Rzeczpospolitej Szlacheckiej na przykładzie Ordynacji Zamojskiej, „Przegląd Geograficzny” 2009, t. 81, z. 2; tenże, Księstwa Rzeczypospolitej. Państwo magnackie jako region polityczny, Warszawa 2013; I. Kriwoszeja, Ewolucja konstrukcji lokalnych ,centrum-prowincja”: transformacja magnackich minipaństw na Ukrainie prawobrzeżnej w latach 1793-1863: na przyktadzie latyfundiów hrabiów Potockich herbu Pilawa „,Studia Europaea Gnesnensia” 2010, t. 1-2; J. Leskiewiczowa, Próba analizy gospodarki dóbr magnackich w Polsce. Dobra wilanowskie na przetomie XVIII i XIX wieku, Warszawa 1964; I. Rychlikowa, Produkcja zboża wielkiej własności w Matopolsce w latach 1764-1805, Warszawa 1967; W. A. Serczyk, Gospodarstwo magnackie w województwie podolskim w drugiej połowie XVIII wieku, Wrocław 1965.

${ }^{3}$ J. Kus, Archiwum Ordynacji Zamojskiej ze Zwierzyńca jako źródto do badań gospodarczych $i$ społecznych latyfundium magnackiego w XVI-XVII w. „Miscellanea Historico-Archivistica” 1998, t. 9; E. Wierzbicka, Znaczenie archiwów rodowych i ich stan przygotowania do badań historycznych na przykładzie archiwaliów książąt Woronieckich z Huszlewa i Lubomirskich z Dubna, „Miscellanea Historico-Archivistica" 1998, t. 9. 
waniu przynajmniej części materiału źródłowego niezbędnego do badań. Mimo wszystko, poza ich obrębem - choć niejednokrotnie w tym samym archiwum - również znajdują się fragmenty archiwów prywatnych. Dobrym na to przykładem jest „Zbiór Zygmunta Glogera”.

Archiwa podworskie, czyli archiwalia powstałe na dworach szlacheckich i magnackich stanowią istotną część zasobu Archiwum Narodowego na Wawelu. Przechowywane są tutaj pozostałości archiwów rodzinnych między innymi Sanguszków, Chodkiewiczów, Tarnowskich i Potockich ${ }^{4}$. Interesujący jest jednak również zespół archiwalny zwany „Zbiorem Zygmunta Glogera”. Jego zaletą jest duża różnorodność. Dokonując kwerendy archiwalnej odnajdujemy w nim materiały genealogiczne i gospodarcze ${ }^{5}$, wypisy z ksiąg grodzkich i ziemskich ${ }^{6}$, inwentarze dóbr ziemskich ${ }^{7}$, inwentarze dóbr ruchomych ${ }^{8}$, korespondencję ${ }^{9}$, a także źródła powstałe $\mathrm{w}$ wyniku funkcjonowania sądownictwa ${ }^{10}$. Znajdują się tutaj wypisy z ksiąg grodzkich i ziemskich (XV-XVIII w.), fragmenty archiwów prywatnych obfitujące w materiały genealogiczne i gospodarcze (XVI-XIX w.), inwentarze nieruchomości (XVI-XVIII w.), źródła sejmowe i sejmikowe (XVII-XIX w.), źródła do historii wojskowości (XVI-XIX w.),a także źródła do dziejów oświaty (XVIII-XIX w.), historii kościoła katolickiego na Podlasiu (XVIII-XIX w.), sądownictwa staropolskiego i porozbiorowego (XVII-XIX w.). Cenny jest zbiór korespondencji prywatnej i królewskiej z XVI-XX w., zbiory kartograficzne i ikonograficzne, a także osiemnastowieczne rękopisy biblioteczne i pamiętnikarskie. Warte uwagi jest Archiwum krakowskiego prawnika Adama Bogusza, zawierające materiały genealogiczne. W większości przypadków ten obfity materiał źródłowy dotyczy zidentyfikowanych rodzin, choć w osobnej jednostce zebrano kwity, obligacje i rewersy rodzin bliżej nieokreślonych ${ }^{11}$. Powstawanie takich źródeł miało związek z potrzebą zabezpieczenia praw do własności ziemskiej, a także

${ }^{4}$ Zainteresowanie takimi archiwami owocuje od dawna opracowaniami analizującymi zasoby archiwalne pod kątem zachowanych w nich fragmentów archiwów prywatnych znanych rodzin doby przedrozbiorowej oraz XIX i XX w. (m.in. B. Smoleńska, Archiwa podworskie w Polsce ludowej, „Archeion” 1955, t. 24; E. Wierzbicka, Archiwa podworskie, rodzinne i rodowe, akta dóbr i osób - stan i opracowanie oraz problemy poziomu i dostęności informacji, „Archeion” 2009/2010, t. 111.

${ }^{5}$ Archiwum Narodowe na Wawelu, Zbiór Zygmunta Glogera (dalej: AN, ZZG), Fragmenty archiwów prywatnych (genealogiczno-gospodarcze) rodzin szlacheckich z pogranicza Podlasia, Litwy i Lubelszczyzny XVI-XX w., nr 67-462.

${ }^{6} \mathrm{AN}, \mathrm{ZZG}$, Wypisy z ksiąg ziemskich i grodzkich podlaskich (tzw. Kapicjana) z XV-XVIII, XVIII-XIX w., nr 1-66.

${ }^{7} \mathrm{AN}, \mathrm{ZZG}$, Inwentarze nieruchomości (starostw, miast, wsi, folwarków) XVI-XIX w., nr 463-550.

${ }^{8} \mathrm{AN}, \mathrm{ZZG}$, Inwentarze ruchomości (odzież, meble, sprzęty gospodarcze) XVI-XVIII w., nr 551-576.

${ }^{9} \mathrm{AN}, \mathrm{ZZG}$, Zbiór korespondencji (m.in. listy królewskie, prywatne i gospodarcze różnych nadawców polskich i obcych) XV-XIX w., nr 750-758.

${ }^{10} \mathrm{AN}, \mathrm{ZZG}$, Papiery do dziejów sądownictwa staropolskiego i porozbiorowego XVII-XIX w, nr 719-726.

${ }^{11}$ AN, ZZG, Zbiór luźnych kwitów, rewersów, obligacji, asygnat różnych, w większości niezidentyfikowanych rodzin szlacheckich 1635-1836, sygn. 29/678/0/2/462. 
udowadniania starych korzeni rodowych. Zakres chronologiczny zawartości „Zbioru Zygmunta Glogera” obejmuje epokę staropolską, a także stulecia XIX i XX (lata 1515-1907). Pod względem geograficznym dotyczy on m.in. Litwy, Podlasia i województwa lubelskiego.

Omawiana kolekcja zainteresowała już badaczy kultury i obyczajowości ${ }^{12}$, wojskowości ${ }^{13}$, społeczeństwa ${ }^{14}$, czy prawa ${ }^{15}$. Z uwagi na jej zawartość można w przyszłości oczekiwać na szersze wykorzystanie zasobu w pracach o charakterze historyczno-prawnym i gospodarczym.

Istotną częścią „Zbioru Zygmunta Glogera” są akta rodzinno-majątkowe. W skład źródeł tego typu wchodzi z reguły korespondencja, księgi rachunkowe, testamenty, dokumenty lub ich odpisy dowodzące praw własności, wypisy z ksiąg sądowych, materiały genealogiczne. W „Zbiorze Zygmunta Glogera” wyróżniają się dokumenty i akta związane z dziejami rodziny Branickich ${ }^{16}$. Dotyczą one głównie wieków XVII i XVIII ${ }^{17}$, ale na uwagę zasługuje inwentarz należącego do tej rodziny pałacu w Białymstoku, datowany na 1809 rok $^{18}$. Zachował się także spisany w 1809 roku inwentarz pałacu w Choroszczy należącego do Potockich ${ }^{19}$. Obszerny jest plik rejestrów klejnotów, domowych sprzętów i kosztownych materii posiadanych przez Sapiehów, pochodzą one bowiem z XVIII i XIX wieku ${ }^{20}$. $\mathrm{Z}$ tego samego okresu pochodzą także rozliczenia finansowe tej rodziny z kupcami ${ }^{21}$.

${ }^{12}$ Zob. np. J. Syguła, Pozycja i rola kobiety $w$ rodzinie na ziemiach polskich $w$ XIX wieku, „Zeszyty Naukowe Uniwersytetu Jagiellońskiego. Prace historyczne" 2009, z. 136.

${ }^{13} \mathrm{~Np}$. L. A. Wierzbicki, Uczestnicy wypraw pospolitego ruszenia koronnego w czasach panowania Michała Korybuta Wiśniowieckiego, [w:] Społeczeństwo a wojsko. Społeczeństwo staropolskie. Seria nowa, t. 4, red. I. M. Dacka-Górzyńska, A. Karpiński i M. Nagielski, Warszawa 2015; M. Sierba, Tykociński przytułek wojskowy w XVII w. - funkcje społeczne i militarne, „Acta Universitatis Lodziensis. Folia Historica" 2015, t. 95.

${ }^{14}$ M. Choińska, Społeczeństwo miasta Tykocina w XVIII i XIX w., Białystok 2013 (praca doktorska); P. Złotkowski, Kim był pótpanek? Analiza apelatywno-proprialna, „Annales Universitatis Mariae Curie-Skłodowska" 2015, t. 33, S. FF.

${ }^{15}$ Zob. np. K. Łopatecki, O instytucji dożywocia na przykładzie matżeństwa Jana Klemensa i Izabeli Branickich, „Krakowskie Studia z Historii Państwa i Prawa” 2016, t. 9, z. 1.

${ }^{16}$ T. Zielińska, Archiwalia dwóch rodów Branickich - herbu gryf i herbu Korczak, ,Miscellanea Historico-Archivistica" 1998, t. 9.

${ }^{17} \mathrm{Z}$ tego okresu możemy tu odnaleźć między innymi zapis obligacyjny Stefana Mikołaja Branickiego na dobrach Orle sporządzony na rzecz Henryka Fleminga (sygn. 29/678/0/2/78), korespondencję hetmana wielkiego koronnego Jana Klemensa Branickiego (sygn. 29/678/0/2/79 i 29/678/0/2/80), akta procesowe Branickich z Tomaszem Czapskim w związku ze starostwem knyszyńskim (sygn. 29/678/0/2/82) i akta miejskie należącego do Branickich Tykocina (sygn. 29/678/0/2/84). $\mathrm{Na}$ osobną uwagę zasługuje inwentarz dóbr knyszyńskich i księgi rachunkowe dóbr tykocińskich (sygn. 29/678/0/2/86 i 29/678/0/2/85).

${ }^{18} \mathrm{AN}$, ZZG, Braniccy. Inwentarz pałacu w Białymstoku 1809 r., sygn. 29/678/0/2/91.

${ }^{19}$ AN, ZZG, Potoccy. Choroszcza - inwentarz pałacu (białostockie) 1809, XIX w., sygn. 29/678/0/2/302.

${ }^{20}$ AN, ZZG, Sapiehowie. Rejestry ruchomości - klejnoty, sprzęty domowe, materie 1728-1752, b.d. (XVIII-XIX w.), sygn. 29/678/0/2/344.

${ }^{21}$ AN, ZZG, Sapiehowie. Rozliczenia z różnymi kupcami 1694-1843, sygn. 29/678/0/2/347. 
Wyróżnia się również zbiór dokumentów z lat 1788-1802 będący odzwierciedleniem problemów prawno-majątkowych żony Jana Klemensa Branickiego, Izabeli z Poniatowskich ${ }^{22}$. Niestety, w omawianym zespole zachowało się niewiele tego typu źródeł odnoszących się do rodziny Jabłonowskich. Z lat 1675 oraz 1749-1828 pochodzą natomiast fragmenty akt majątkowych miecznika podlaskiego Antoniego Jabłonowskiego ${ }^{23}$. Część akt majątkowo-prawnych zachowała się w przypadku Skibickich ${ }^{24}$, Śliwowskich ${ }^{25}$ i Żeleńskich ${ }^{26}$.

W zachowanym zasobie „Zbioru Zygmunta Glogera” obecne są jednak także większe fragmenty pieczołowicie niegdyś gromadzonych szlacheckich archiwów. Znajdują się tutaj pozostałości archiwum rodzinnego Barzów, wśród których łatwo odnaleźć dokumenty i akta związane z dziedziczeniem dóbr tej rodziny ${ }^{27}$. Niemniej istotne znaczenie mają dokumenty obrazujące konflikty powstałe w wyniku sporów o dobra ziemskie. Przykładem na to mogą być materiały pochodzące z archiwum rodzinnego Biedrzychowskich toczących walkę o majątek z Oleśnickimi ${ }^{28}$. Z pierwszej połowy XIX wieku pochodzą akta majątkowo-procesowe Rembielińskich $^{29}$, a także akta separacyjne i spadkowe wchodzące niegdyś w skład archiwum Potockich. Wśród nich wyróżniają się dokumenty powstałe dzięki spadkowi, który Jan, Feliks i Joanna Potoccy uzyskali po śmierci podczaszego litewskiego Joachima Karola Potockiego ${ }^{30}$, a także dokumenty związane z separacją i rozliczeniami majątkowymi między Janem Alojzym Potockim i jego pierwszą żoną Marianną z Czartoryskich ${ }^{31}$.

Fragmenty akt prawno-majątkowych zawiera jednostka skupiająca pozostałości archiwum rodzinnego Bielskich ${ }^{32}$, a uwagę zwracają także charakteryzujące się szerokim zakresem chronologicznym fragmenty akt prawno-majątkowych Biskup-

${ }^{22} \mathrm{AN}, \mathrm{ZZG}$, Braniccy - Izabella z Poniatowskich, żona Jana Klemensa. Sprawy prawno-majątkowe 1788-1802, sygn. 29/678/0/2/90.

${ }^{23} \mathrm{AN}, \mathrm{ZZG}$, Jabłonowscy h. Grzymała - Antoni, miecznik podlaski. Drobne fragmenty akt majątkowych 1675 oraz 1749-1828, sygn. 29/678/0/2/154.

${ }^{24}$ AN, ZZG, Skibiccy h. Rola. Fragmenty akt majątkowych Wojciecha Skibickiego dotyczące majątku Zambrzyce i Konopki Leśne 1782-1807, sygn. 29/678/0/2/355.

${ }^{25}$ AN, ZZG, Śliwowscy h. Grzymała. Fragmenty akt majątkowych dotyczących Brzeźnicy Szlacheckiej, m.in. plenipotencje, priora majątkowe1787, 1798-1811, 2) Tarnowski. Wola Tarnowska 1658, 3) Szczawiński 1687, sygn. 29/678/0/2/407.

${ }^{26}$ AN, ZZG, Żeleńscy z Grotkowic. Akta prawno-majątkowe - obligacje gromadzkie ze wsi Dąbrowa, Szarów, Brzezie (bocheńskie), 2) Żędzionowie 1728, 1753 1728-1816, sygn. 29/678/0/2/455.

${ }^{27}$ AN, ZZG, Barzowie. Akta rodzinno-majątkowe (sprawy dziedziczenia dóbr), sygn. 29/678/0/2/69.

${ }^{28}$ AN, ZZG, Biedrzychowscy. Akta rodzinno-majątkowe, spory z Oleśnickimi, sygn. 29/678/0/2/71.

${ }^{29}$ AN, ZZG, Rembielińscy h. Lubicz. Fragmenty akt majątkowo-procesowych z dołączonymi aktami folwarku Kołomyja (sejneńskie) z lat 1832-1841, sygn. 29/678/0/2/312.

${ }^{30}$ AN, ZZG, Potoccy Jan, Feliks, Joanna. Spadek po Joachimie Karolu Potockim, podczaszym Wielkiego Księstwa Litewskiego, sygn. 29/678/0/2/289.

${ }^{31}$ AN, ZZG, Potoccy - Jan, Alojzy. Sprawy separacji i rozliczeń majątkowych z pierwszą żoną, Marianną z Czartoryskich, sygn. 29/678/0/2/290.

${ }^{32}$ AN,ZZG, Fragmenty akt prawno-majątkowych (dot. m.in. Zakrzowa) 1717-1838, sygn. 29/678/0/2/72. 
skich. Wyróżniają się one również pod względem kryterium terytorialnego, są tu bowiem wypisy z ksiąg sądowych kilku grodów wielkopolskich ${ }^{33}$. Spory rodzinno-majątkowe z rodziną Woynów zawierają papiery pozostałe po Błeszyńskich ${ }^{34}$.

Niemniej interesujące są dokumenty prezentujące sprawę sukcesji majątku po śmierci Stanisława Kossakowskiego, pochodzące z lat 1809-1850 ${ }^{35}$. O miasteczko Kościelec - własność Gołuchowskich - toczył się spór między Różą Gołuchowską a rodziną Borowskich, co naświetla dokument z 1856 roku $^{36}$. Sprawom spadkowym, a także aktom kupna i sprzedaży Maluszyc i Wołcza w 1589 roku oraz w latach 1601-1809 poświęcone są papiery z archiwum gospodarczego Meleszyckich ${ }^{37}$.

Zaletą akt majątkowo-rodzinnych Suchodolskich jest ich rozpiętość chronologiczna. Akta spadkowe tej rodziny, dzielenie majątku i rozliczenia pochodzą bowiem z XVII-XVIII wieku oraz z $1810 \mathrm{roku}^{38}$. Podobna uwaga nasuwa się w przypadku reliktów archiwum rodzinnego Szmurłów z uwagi na to, że zachowane akta procesowe tej rodziny ze Śliwińskimi i Topczewskimi dotyczące Brzeźnicy są datowane na XVII-XIX wiek ${ }^{39}$. Istotną wartość mogą mieć dla badacza dokumenty Woynów procesujących się o Woyny, Szuby i Bakałarze z Wyszyńskimi i Błeszyńskimi oraz Kobylińskimi i Maliszewskimi ${ }^{40}$.

Z uwagi na umacniającą się społeczną i polityczną pozycję Potockich i Poniatowskich, na uwagę zasługują zachowane w „Zbiorze Zygmunta Glogera” dokumenty spadkowe spisane po śmierci podczaszego litewskiego Joachima Karola Potockiego $^{41}$, a także akt sprzedaży należących do Józefa i Karola Poniatowskich

${ }^{33}$ AN, ZZG, Biskupscy. Fragmenty akt prawno-majątkowych (wypisy z ksiąg sądowych wielkopolskich: poznańskich, gnieźnieńskich, kaliskich, pyzdrskich) [1618] 1748-1804, sygn. 29/ 678/0/2/73.

${ }^{34}$ AN, ZZG, Błeszyńscy h. Oksza. Akta rodzinno-majątkowe (fragmenty), m.in. dot. Karola, cześnika żytomirskiego, spory z Woynami o części na dobrach Wojny, Szuby, Bakałarze 1. 1613-1795, sygn. 29/678/0/2/75.

${ }^{35}$ AN, ZZG, Kossakowscy h. Ślepowron. Sprawa sukcesji majątku po Stanisławie Kossakowski 1809-1850, sygn. 29/678/0/2/184.

${ }^{36}$ AN, ZZG, Gołuchowscy h. Leliwa. Sprawa Róży Gołuchowskiej z Borowskimi o dobra Kościelec 1856 r., sygn. 29/678/0/2/143.

${ }^{37}$ AN, ZZG, Meleszyccy h. Ułan. Działy majątkowe, sprawy spadkowe, akta kupna i sprzedaży dotyczące Małuszyc i Wołcza w nowogrodzkim (1589) 1601-1809, sygn. 29/678/0/2/230.

${ }^{38}$ AN, ZZG, Suchodolscy h. Pobóg. Akta majątkowo-rodzinne (spadkowe, podziały schedy, rozliczenia), spory m.in. z Łempiczami, Niemyskimi - dobra Winna, Wypychy (drohickie), 2) Palczowscy. Polanka Górna i Dolna 1638-1810, sygn. 29/678/0/2/372.

${ }^{39}$ AN, ZZG, Szmurłowie. Fragmenty akt majątkowo-procesowych ze Śliwowskimi i Topczewskimi dotyczących Brzeźnicy (łomżyńskie) 1683-1804, sygn. 29/678/0/2/397.

${ }^{40}$ AN, ZZG, Woynowie h. Trąby - Ludwik. Akta rodzinno-majątkowe. Sprawy z rodzinami spowinowaconymi, m.in. Wyszyńskimi, Błeszyńskimi (priora rodzinno-majątkowe) 1627-1843, sygn. 29/678/0/2/429; Woynowie h. Trąby. Akta procesowe dotyczące dóbr Woyny, Szuby, Bakałarze i in. z Kobylińskimi i Maliszewskimi 1725-1830, sygn. 29/678/0/2/432.

${ }^{41}$ AN, ZZG, Potoccy - Jan, Feliks, Joanna. Spadek po Joachimie Karolu, podczaszym Wielkiego Księstwa Litewskiego 1802, sygn. 29/678/0/2/289. 
dóbr Skałat z 1862 roku $^{42}$. Układy Zamoyskich z Krasińskimi, Czartoryskimi ${ }^{43}$ i Sapiehami - także w pierwszej połowie XIX wieku - są naświetlone dzięki aktom prawno-majątkowym i kwitom ${ }^{44}$.

Zachowane dokumenty ujawniają spory finansowe także między rodzinami szlacheckimi i magnackimi a Kościołem. Przykładem tego może być wieloletni konflikt między Męcińskimi a paulinami jasnogórskimi o sumy pieniężne i depozyty, toczący się w XVIII i w pierwszej połowie XIX wieku ${ }^{45}$. Kwity finansowe związane z różnymi kościołami i klasztorami znajdują się z kolei wśród dokumentów generała wojsk koronnych Kazimierza Szembeka ${ }^{46}$. Merytoryczną i chronologiczną ciągłością charakteryzują się papiery Zaleskich związane między innymi z kościołem w Kobylanach na przestrzeni lat 1738-1848 4 .

Kolejną grupę dokumentów stanowią kontrakty dzierżawne. Z 1791 roku pochodzi umowa w tej sprawie dotycząca młyna należącego do rodziny Kostrów, wydzierżawionego Łaniewskim ${ }^{48}$. Cenny jest także plik dokumentów z lat 1744-1818 związany z dzierżawą miasteczka Bazalia należącego do Krosnowskich $^{49}$. Na uwagę zasługuje także dokument z 1846 roku omawiający sprawy dzierżaw rodziny Rejów w Raniżowie ${ }^{50}$ oraz Woynów ${ }^{51}$.

Kontrakty dzierżawne były niejednokrotnie osnową sporów między Potockimi a ich żydowskimi dzierżawcami. Między obu stronami toczyły się także negocjacje w sprawie wysokości podatków, co dobrze oddają dokumenty powstałe w XVIII wieku i w pierwszej połowie XIX stulecia ${ }^{52}$.

${ }^{42}$ AN, ZZG, Poniatowscy - Józef, Karol. Sprawa sprzedaży dóbr Skałat 1862, sygn. 29/678/0/2/303.

${ }^{43}$ Zob. np. P. Sieradzki, Obecność rodziny książat Czartoryskich na ziemi jarosławskiej. Zarys problematyki, „Teka Kom. Hist. OL PAN” 2006, nr 1.

${ }^{44}$ AN, ZZG, Zamojscy. Ordynacja. Układy majątkowe z Krasińskiaktom prawno-majątkowym i, Sapiehami, Czartoryskimi. Akta prawno-majątkowe 1643, 1804-1830, kwit z 1643 r., sygn. 29/ 678/0/2/441.

${ }^{45} \mathrm{AN}, \mathrm{ZZG}$, Męcińscy h. Poraj. Akta procesu z paulinami jasnogórskimi o sumy pieniężne i depozyty 1754, 1824, 1842-1846, sygn. 29/678/0/2/234.

${ }^{46}$ AN, ZZG, Szembekowie - Kazimierz, generał wojsk koronnych. Kwity różnych kościołów i klasztorów z odebranej prowizji 1775-1814, sygn. 29/678/0/2/395.

${ }^{47}$ AN, ZZG, Zalescy. Papiery majątkowe dotyczące dóbr Szmurly (działy rodzinne). Sprawy kościoła w Kobylanach 1738-1848, sygn. 29/678/0/2/439.

${ }^{48}$ AN, ZZG, Kostrowie. Kontrakt z Łuniewskimi na dzierżawę młyna; 1750 2) Koszkowscy - Jakub i Leonard. Wezwanie do świadczenia w sądzie grodzkim brańskim 1791, sygn.. 29/678/0/2/185.

${ }^{49}$ AN, ZZG, Krosnowscy - Antoni, Józef. Akta majątkowe związane z dzierżawą miasteczka Bazalia (krzemienieckie) 1744-1818, sygn. 29/678/0/2/195.

${ }^{50}$ AN, ZZG, Rejowie h. Oksza. Raniżów - sprawy dzierżawcze (powiat kolbuszowski) 1846, sygn. 29/678/0/2/311.

${ }^{51}$ AN, ZZG, Woynowie h. Trąby. Materiały rodzinno-majątkowe. Koligacje z Kuczyńskimi (umowy dzierżawne, intercyzy ślubne, wyciągi metrykalne) (1612) 1667-1687, 1719-1823, sygn. 29/678/0/2/430.

${ }^{52}$ AN, ZZG, Potoccy. Spory z Żydami wynikłe z kontraktów dzierżawnych. Prośba Żydów z Boćków do Jana Potockiego w sprawie wymiaru podatków 1705, 1785, 1787, 1805, 1818, sygn. 29/678/0/2/295. 
Problemy gospodarcze w latyfundium Czartoryskich ${ }^{53}$ dobrze przedstawia ich korespondencja prowadzona między innymi z Eustachym Sanguszką, tym bardziej, że jej ramy chronologiczne są szerokie i obejmują zarówno rok 1768 jak i pierwsze ćwierćwiecze stulecia XIX ${ }^{54}$. W przypadku księcia Adama Jerzego Czartoryskiego można tu odnaleźć fragment spisu należących do niego ruchomości datowany na okres po 1811 roku $^{55}$. Dla badaczy dóbr wielkiej własności ziemskiej użyteczne będą także źródła dotyczące należących do Czartoryskich dóbr litewskich, podlaskich, bieżuńskich, żuramińskich i wysockich ${ }^{56}$.

Z lat 1794-1817 pochodzą dokumenty rodzinne księcia Adama Kazimierza, Izabeli z Flemingów, Konstantego i Zofii z Czartoryskich ${ }^{57}$ Zamoyskiej $^{58}$. Księgi dochodów i wydatków datowane na różne lata XIX wieku powstały między innymi na dworze Sapiehów ${ }^{59}$. Z lat 1803-1809 pochodzą kwity potwierdzające odbiór gotówki w dobrach ziemskich Magdaleny Dulskiej ${ }^{60}$. Pod względem chronologicznym wyróżniają się natomiast księgi rachunkowe skarbu prywatnego Sapiehów, obejmując lata $1724-1804^{61}$. Z podobnego okresu pochodzi księga przychodów i rozchodów dóbr ołyckich należących do Radziwiłłów, jest bowiem datowana na 1808 rok $^{62}$. Dzieje rozbudowy kompleksu dóbr ziemskich tej potężnej niegdyś litewskiej rodziny magnackiej od dawna cieszą się zainteresowaniem badaczy, ale brakuje monografii ukazujących tę problematykę począwszy od połowy XVI po XIX wiek ${ }^{63}$.

${ }^{53}$ Zob. np. A. Michalski, Działalność gospodarcza książat Czartoryskich w księstwie klewańskim w l. 1701-1741, Słupsk 2012.

${ }^{54}$ AN, ZZG, Czartoryscy - Adam, Konstanty, Maria. Korespondencja od Eustachego Sanguszki dotycząca spraw gospodarczych klucza zinkowskiego (latyczowskie) 1768 oraz 1822-1824, sygn. 29/678/0/2/107.

${ }^{55}$ AN, ZZG, Czartoryscy-Adam Jerzy. Fragment spisu ruchomości po 1811 r., sygn. 29/678/0/2/108.

${ }^{56} \mathrm{AN}, \mathrm{ZZG}$, Czartoryscy. Dobra litewskie. podlaskie, bieżuńskie, żuramińskie i wysockie - remanenty, raporty, tytuły prawne, sygn. 29/678/0/2/110.

${ }^{57}$ P. Sieradzki, Znaczenie dóbr Sieniawskich dla Czartoryskich $w$ emigracyjnych realiach popowstaniowych, „Teka Kom. Hist. - OL PAN” 2011, t. 8.

${ }^{58}$ AN, ZZG, Czartoryscy. Akta prawno-majątkowe: a) Adama 1794-1817; b) Izabelli 17981811; c) Konstantego 1801-1813; d) Zofii z Czartoryskich Zamoyskiej 1816, sygn. 29/678/0/2/111.

${ }^{59}$ AN, ZZG, Sapiehowie. Rejestry percepty i ekspensy pieniężnej skarbu 1724-1804, sygn. 29/678/0/2/346. Zob. m.in. Sapiehowie kodeńscy: historia rodu od kolebki do wspótczesności, red. A. Tłomacki, Warszawa 2009; H. Mierzwiński, Księżna Anna Paulina z Sapiehów Jabłonowska (1728-1800), „Szkice Podlaskie” 1999, nr 7.

${ }^{60}$ AN, ZZG, Dulscy - Magdalena. Potwierdzenie odbioru kwot pieniężnych 1803-1809, sygn. 29/678/0/2/125.

${ }^{61}$ AN, ZZG, Sapiehowie. Rejestry percepty i ekspensy pieniężnej skarbu 1724-1804, sygn. 29/678/0/2/346. Zob. także A. Rachuba, Archiwa Sapiehów - ich losy i stan obecny, „Miscellanea Historico-Archivistica" 1998, t. 9.

${ }^{62}$ AN, ZZG, Radziwiłłowie. Księga przychodów i rozchodów w hrabstwie ołyckim 1808, sygn. 29/678/0/2/309.

${ }^{63}$ M.in. M. Malczewska, Latyfundium Radziwittów w XV do połowy XVI w. Warszawa 1985; Z. Anusik, A. Stroynowski, Radziwiłlowie w epoce saskiej. Zarys dziejów politycznych i majątkowych, „Acta Universitatis Lodziensis. Folia Historica” 1989, t. 33. 
W „Zbiorze Zygmunta Glogera” znajdziemy także fragmenty rodzinnego archiwum Denhoffów. Z 1699 roku, a także z XVIII i XIX wieku, pochodzą inwentarze ruchomości tej rodziny, między innymi wojewodzianki malborskiej Joanny, żony hetmana polnego litewskiego Stanisława Denhoffa ${ }^{64}$. Jak dotąd, badaczy interesowały głównie wojskowe aspekty działalności tej rodziny w Rzeczypospolitej ${ }^{65}$.

Uzupełnieniem archiwów podworskich są wpisy zamieszczane w księgach sądowych. Na schyłkowych latach XVIII wieku kończą się wypisy z ksiąg sądowych brańskich ${ }^{66}$. Odnajdziemy tu także kopie relacji, dekretów i fragmentów ksiąg wieczystych odnotowanych w księgach grodzkich brańskich ${ }^{67}$ Z drugiej połowy XVIII wieku pochodzą także odpisy dokumentów publikowanych w księgach sądowych bielskich ${ }^{68}$. Lat 1688-1798 dotyczą wpisy w księgach sądowych goniądzkich ${ }^{69}$.

Rzadkością są w „Zbiorze Zygmunta Glogera” testamenty. Do unikatów można więc tu zaliczyć akt ostatniej woli majora Józefa Aleksandra Hiży z 1812 roku $^{70}$. Akta, datowane na połowę XIX wieku, związane z opieką nad małoletnimi dziećmi przechowywali w swoim archiwum Jaczyńscy h. Jastrzębiec ${ }^{71}$.

W dokumentach gospodarczych badacz odnajduje tzw. ,zapisy”, czyli zabezpieczenia pożyczek na dobrach ziemskich. W przypadku rodziny Karwowskich zachowały się dwa dokumenty tego typu datowane na 1790 i 1803 rok. Odnotowały one sprawę zadłużenia Franciszka Karwowskiego na dobrach Bajki na rzecz rodziny Dolińskich ${ }^{72}$.

${ }^{64}$ AN, ZZG, Denhoffowie - Joanna z Denhoffów, wojewodzianka malborska, żona Stanisława, hetmana polnego litewskiego. Inwentarze ruchomości, m.in. pozostałych po śmierci męża 1699, 1704-1845, sygn. 29/678/0/2/121.

${ }^{65}$ Zob. m.in. H. J. Bömelburg, Między Inflantami, Prusami i Rzeczpospolita. Kariera rodu Denhoffów (1580-1650), [w:] Prusy i Inflanty między średniowieczem a nowożytnością. Państwo - społeczeństwo - kultura, red. B. Dybaś i D. Makiłła, Torun 2003.

${ }^{66} \mathrm{AN}, \mathrm{ZZG}$, Odpisy dokumentów z ksiąg sądowych brańskich (nadwornych) 1555-1790, sygn. 29/678/0/1/9; Odpisy dokumentów z ksiąg sądowych brańskich (grodzkich) 1740-1797, sygn. 29/678/0/1/10.

${ }^{67} \mathrm{AN}, \mathrm{ZZG}$, Odpisy dokumentów z ksiąg grodzkich brańskich: relacji, dekretów, ksiąg wieczystych 1537-1791, sygn. 29/678/0/1/20.

${ }^{68}$ AN, ZZG, Odpisy dokumentów z ksiąg sądowych bielskich 1768-1791, sygn. 29/678/0/1/24.

${ }^{69}$ AN, ZZG, Odpisy dokumentów z ksiąg sądowych grodzkich goniądzkich (relacje) 1688-1798, sygn. 29/678/0/1/39.

${ }^{70}$ AN, ZZG, Hiżowie h. Jeż. Testament Józefa Aleksandra, majora wojsk polskich 1812 r., sygn. 29/678/0/2/149.

${ }^{71}$ AN, ZZG, Akta opiekuńcze nieletnich: Władysława, Julianny, Gustawa, Zofii 1840 i Ludwika 1840-1858, sygn. 29/678/0/2/155; Szlachta wylegitymowana w Królestwie Polskim $w$ latach 1836-1861(1867), oprac. E. Sęczys i S. Górzyński, Warszawa 2007.

${ }^{72}$ AN, ZZG, Karwowscy - Franciszek. Sprawa zapisu na dobrach Bajki na rzecz Dolińskich 1790, 1803, sygn. 29/678/0/2/170. 
Omawiane dokumenty dotyczą $\mathrm{z}$ reguly dóbr ziemskich, ale niektóre $\mathrm{z}$ nich odnoszą się także do szlacheckiej własności w mieście. Z 1813 roku pochodzi dokument omawiający sprawę zakupu kamienicy we Lwowie przez rodzinę Komorowskich ${ }^{73}$.

Interesującą grupę dokumentów i akt stanowią te spośród nich, które powstały $\mathrm{w}$ wyniku rozbudowy przemysłu $\mathrm{w}$ dobrach wielkiej własności ziemskiej. W przypadku latyfundium Lubomirskich ${ }^{74}$ zachowały się raporty fabryki sukna w Korcu datowane na lata $1814-1815^{75}$. Działalność fabryki we Frączkowie i giserni w Tykocinie znalazła swoje rachunkowe odzwierciedlenie w dokumentach $\mathrm{z}$ archiwum rodzinnego Potockich ${ }^{76}$.

Różnorodność zawartości „Zbioru Zygmunta Glogera” jest w równej mierze zaletą, jak i wadą. Zamieszczone w nim akta i dokumenty mogą być cennym niekiedy uzupełnieniem bazy źródłowej, ale nie wyczerpują potrzeb badacza starającego się kompletować archiwa prywatne szlachty i wielkiej własności ziemskiej. Mimo to, z uwagi na obszerne niekiedy ramy chronologiczne i ciągłość merytoryczną, omawiana tu kolekcja daje możliwość wzbogacenia naszej wiedzy o dodatkowe informacje, związane przede wszystkim z problemami majątkowymi i gospodarczymi. Daje również sposobność do bliższego przyjrzenia się więzom łączącym rodziny szlacheckie i magnackie na bazie pokrewieństwa, powinowactwa oraz zgodnych lub sprzecznych interesów majątkowych.

${ }^{73}$ AN, ZZG, Komorowscy. Kupno kamienicy Godaszowskich we Lwowie 1813 r., sygn. 29/678/0/2/179.

${ }^{74}$ Charakterystyka o charakterze monograficznym majątku tej rodziny obejmuje jedynie XVII w. (J. Długosz, Latyfundia Lubomirskich w XVII wieku: (Powstanie, rozwój, podziaty), Wrocław 1997; zob. także K. Przyboś, Materiały do dziejów latyfundium Lubomirskich. Podział majatku Stanisława Lubomirskiego w l. 1642-1649, „Przemyskie Zapiski Historyczne” 1991-1992, R. 8-9). Chronologicznie bliższa naszym czasom jest praca poświęcona handlowi zbożowemu tej rodziny (A. Homecki, Produkcja i handel zbożowy w latyfundium Lubomirskich $w$ drugiej połowie XVII i pierwszej XVIII wieku, Wrocław 1970.

${ }^{75}$ AN, ZZG, Lubomirscy. Raporty fabryki sukienniczej w Korcu (kwartalne i półroczne) 1814 1815, sygn. 29/678/0/2/218. Adam Homecki opracował wątek rozwoju terytorialnego latyfundium Lubomirskich do połowy XVIII w. (A. Homecki, Rozwój terytorialny latyfundium Lubomirskich (starszej gatęzi rodu) w latach 1581-1754, „Studia Historyczne” 1972, t. 15, z. 3).

${ }^{76} \mathrm{AN}, \mathrm{ZZG}$, Potoccy. Rachunek fabrykantów przy fabryce frączkowskiej. Gisernia w Tykocinie 1830-1832, sygn. 29/678/0/2/301. 
Magdalena Ujma

\section{PRIVATE ARCHIVES OF NOBLE FAMILIES FROM THE BORDER PODLASIE AND LUBLIN AND LITHUANIA IN THE EIGHTEENTH AND NINETEENTH CENTURIES (THE COLLECTION OF ZYGMUNT GLOGER IN THE STATE ARCHIVE OF THE WAWEL)}

The primary source of knowledge in the subject careers are documents and files stored in the archives of the once private. Their pieces are among others in the ECR Zygmunt Gloger. Its advantage is a large variety. We find in the genealogical material and economic, excerpts from books municipal and earthly, worldly goods inventories, inventories of movable property, correspondence, and sources resulting from the functioning of the judiciary. Here are excerpts private archives rich in genealogical material and economic. The chronological range of content „Compendium Zygmunt Gloger" includes the era of traditional Polish as well as centuries XIX and XX (1. 1515-1907). Geographically it concerns among other things, Lithuania, Podlasie and Lublin province.

An important part of the „Collection of Zygmunt Gloger” are records of family and property. The sources of this type generally includes correspondence, accounts, wills, documents or their copies proving ownership, extracts from court records, genealogical material. In the ECR Zygmunt Gloger stand out documents and files related to history: Branickich, Barzów, Biedrzychowskich, Potocki, Bielski, Woynów, Suchodolski, Poniatowski, Zamoyski, Czartoryski, Szembeków, Sapieha, the Radziwill, Denhoff, Lubomirski.

Słowa kluczowe: Zbiór, Gloger, archiwa rodzinne, szlachta, magnateria

Keywords: Collection, Gloger, the family archives, nobility, nobility

\section{BIBLIOGRAFIA}

\section{Źródła rękopiśmienne}

Archiwum Narodowe na Wawelu:

Zbiór Zygmunta Glogera

- Fragmenty archiwów prywatnych (genealogiczno-gospodarcze) rodzin szlacheckich z pogranicza Podlasia, Litwy i Lubelszczyzny XVI-XX w., nr 67-462.

- Wypisy z ksiąg ziemskich i grodzkich podlaskich (tzw. Kapicjana) z XV-XVIII, XVIII-XIX w., nr 1-66.

- Inwentarze nieruchomości (starostw, miast, wsi, folwarków) XVI-XIX w., nr 463-550.

- Inwentarze ruchomości (odzież, meble, sprzęty gospodarcze) XVI-XVIII w., nr 551-576.

- Zbiór korespondencji (m.in. listy królewskie, prywatne i gospodarcze różnych nadawców polskich i obcych) XV-XIX w., nr 750-758.

- Papiery do dziejów sądownictwa staropolskiego i porozbiorowego XVII-XIX w, nr 719-726.

- Zbiór luźnych kwitów, rewersów, obligacji, asygnat różnych, w większości niezidentyfikowanych rodzin szlacheckich 1635-1836, sygn. 29/678/0/2/462. 


\section{Opracowania}

Anusik Z., Stroynowski A., Radziwiłlowie w epoce saskiej. Zarys dziejów politycznych i majątkowych, „Acta Universitatis Lodziensis. Folia Historica" 1989, t. 33.

Bömelburg J., Między Inflantami, Prusami i Rzeczpospolitą. Kariera rodu Denhoffów (1580-1650), [w:] Prusy i Inflanty między średniowieczem a nowożytnością. Państwo - społeczeństwo - kultura, red. B. Dybaś i D. Makiłła, Toruń 2003.

Choińska M., Społeczeństwo miasta Tykocina w XVIII i XIX w., Białystok 2013 (praca doktorska).

Długosz J., Latyfundia Lubomirskich w XVII wieku: (Powstanie, rozwój, podziały), Wrocław 1997.

Homecki A., Produkcja i handel zbożowy w latyfundium Lubomirskich w drugiej połowie XVII i pierwszej XVIII wieku, Wrocław 1970.

Homecki A., Rozwój terytorialny latyfundium Lubomirskich (starszej gałęzi rodu) w latach 1581-1754, „Studia Historyczne" 1972, t. 15, z. 3.

Karolczak K., Dzieduszyccy. Dzieje rodu. Linia poturzycko-zarzecka, Kraków 2001.

Kowalski M., Księstwa Rzeczypopolitej. Państwo magnackie jako region polityczny, Warszawa 2013.

Kowalski M., Państwo magnackie w strukturach polityczno-administracyjnych Rzeczpospolitej Szlacheckiej na przykładzie Ordynacji Zamojskiej, „Przegląd Geograficzny” 2009, t. 81, z. 2.

Kriwoszeja I., Ewolucja konstrukcji lokalnych „,centrum-prowincja”: transformacja magnackich minipaństw na Ukrainie prawobrzeżnej w latach 1793-1863: na przykładzie latyfundiów hrabiów Potockich herbu Pilawa, „Studia Europaea Gnesnensia” 2010, t. 1-2.

Kus J., Archiwum Ordynacji Zamojskiej ze Zwierzyńca jako źródło do badań gospodarczych i społecznych latyfundium magnackiego w XVI-XVII w., „Miscellanea Historico-Archivistica” 1998, t. 9.

Leskiewiczowa J., Próba analizy gospodarki dóbr magnackich w Polsce. Dobra wilanowskie na przełomie XVIII i XIX wieku, Warszawa 1964.

Łopatecki K., O instytucji dożywocia na przykładzie matżeństwa Jana Klemensa i Izabeli Branickich, „Krakowskie Studia z Historii Państwa i Prawa” 2016, t. 9, z. 1.

Malczewska M., Latyfundium Radziwiłtów w XV do połowy XVI w., Warszawa 1985.

Mączak A., Pieniądz i społeczeństwo w Rzeczypospolitej XVI-XVIII wieku, „Rocznik Dziejów Społecznych i Gospodarczych" 1976, t. 37.

Michalski A., Działalność gospodarcza książąt Czartoryskich w księstwie klewańskim w l. 1701-1741, Słupsk 2012.

Mierzwiński H., Księżna Anna Paulina z Sapiehów Jabłonowska (1728-1800), „Szkice Podlaskie” 1999 , nr 7.

Półćwiartek J., Latyfundium rzeszowskie, [w:] Dzieje Rzeszowa, t. 1, Rzeszów 1994.

Przyboś K., Materiały do dziejów latyfundium Lubomirskich. Podział majątku Stanisława Lubomirskiego w l. 1642-1649, „Przemyskie Zapiski Historyczne” 1991-1992, R. 8-9.

Rachuba A., Archiwa Sapiehów - ich losy i stan obecny, „Miscellanea Historico-Archivistica” 1998, t. 9.

Rychlikowa I., Produkcja zboża wielkiej własności w Małopolsce w latach 1764-1805, Warszawa 1967.

Sapiehowie kodeńscy: historia rodu od kolebki do współczesności, red. A. Tłomacki, Warszawa 2009.

Serczyk W. A., Gospodarstwo magnackie w województwie podolskim w drugiej połowie XVIII wieku, Wrocław 1965.

Sieradzki P., Obecność rodziny książą Czartoryskich na ziemi jarosławskiej. Zarys problematyki, „Teka Kom. Hist. OL PAN" 2006, nr 1.

Sieradzki P., Znaczenie dóbr Sieniawskich dla Czartoryskich w emigracyjnych realiach popowstaniowych, ,Teka Kom. Hist. - OL PAN" 2011, t. 8. 
Sierba M., Tykociński przytułek wojskowy w XVII w. - funkcje społeczne i militarne, „Acta Universitatis Lodziensis. Folia Historica" 2015, t. 95.

Smoleńska B., Archiwa podworskie w Polsce ludowej, „Archeion” 1955, t. 24.

Syguła J., Pozycja i rola kobiety $w$ rodzinie na ziemiach polskich w XIX wieku, „Zeszyty Naukowe Uniwersytetu Jagiellońskiego. Prace historyczne” 2009, z. 136.

Szlachta wylegitymowana w Królestwie Polskim w latach 1836-1861 (1867), oprac. E. Sęczys i S. Górzyński, Warszawa 2007.

Wierzbicka E., Archiwa podworskie, rodzinne i rodowe, akta dóbr i osób - stan i opracowanie oraz problemy poziomu i dostępności informacji, „Archeion” 2009/2010, t. 111.

Wierzbicka E., Znaczenie archiwów rodowych i ich stan przygotowania do badań historycznych na przykładzie archiwaliów książąt Woronieckich z Huszlewa i Lubomirskich z Dubna, ,Miscellanea Historico-Archivistica" 1998 , t. 9.

Wierzbicki L.A., Uczestnicy wypraw pospolitego ruszenia koronnego w czasach panowania Michała Korybuta Wiśniowieckiego, [w:] Społeczeństwo a wojsko. Społeczeństwo staropolskie. Seria nowa, t. 4, red. I. M. Dacka-Górzyńska, A. Karpiński i M. Nagielski, Warszawa 2015.

Złotkowski P., Kim był pótpanek? Analiza apelatywno-proprialna, „Annales Universitatis Mariae Curie-Skłodowska" 2015, t. 33, s. FF. 